Article

\title{
Recording Permanence and Ephemerality in the North Quarter of Brussels: Drawing at the Intersection of Time, Space, and People
}

\author{
Claire Bosmans *, Racha Daher and Viviana d'Auria \\ Department of Architecture, KU Leuven, 3001 Heverlee, Belgium; E-Mails: claire.bosmans@kuleuven.be (C.B.), \\ racha.daher@kuleuven.be (R.D.), viviana.dauria@kuleuven.be (V.d'A.) \\ * Corresponding author
}

Submitted: 1 January 2020 | Accepted: 4 May 2020 | Published: 30 June 2020

\begin{abstract}
Lying in the Senne River Valley, the North Quarter of Brussels is a physical record of spatial transformations unevenly distributed over time. Waves of developments and unfinished plans colonized its original landscape structure, erasing, writing, and re-writing it with large-scale metropolitan projects and transportation systems, around which an industrial and urban fabric developed. Accumulated expansions left an assemblage of incomplete infrastructures in which a multi-faceted and highly identifiable quarter lies punctuated by weakly defined morphological mismatches. At the center of this diverse and mutilated fabric, Maximilien Park stands as pars pro toto. From a combination of research methods that includes ethnographic fieldwork and interpretative mapping, three drawings are overlaid with the moving dimensions of space, time, and people, and assembled in a reinterpreted triptych to investigate the production of that public space. The first panel "Traces" overlaps lost urban logics and remaining traces on the urban tissue. The second panel "Cycles" traces the uneven deconstruction of the North Quarter during the last century, identifying scars of its past. The third panel "Resignifications" focuses on recent events in the area, examining how people have appropriated and transformed the park since 2015 . With this triptych, the article aims to re-interpret the palimpsest of the North Quarter, represent the area's transforming character, and unravel a spatial reading of the lived experiences of the place through time.
\end{abstract}

\section{Keywords}

cycle; mapping; Maximilien Park; North Quarter; palimpsest; resignification; urban ethnography; urban regeneration

Issue

This article is part of the issue "Territories in Time: Mapping Palimpsest Horizons" edited by Chiara Cavalieri (UCLouvain, Belgium) and Elena Cogato Lanza (EPFL, Switzerland).

(C) 2020 by the authors; licensee Cogitatio (Lisbon, Portugal). This article is licensed under a Creative Commons Attribution 4.0 International License (CC BY).

\section{Intermittent Cycles of Urban Regeneration}

In his analogy between land and palimpsest, Corboz (1983) stresses the multiple processes that constantly shape and reshape a territory, oscillating between natural transformations and human activities. The land is a moving project, a draft forever erased and re-written by a countless list of authors, such as inhabitants, public authorities, market changes, and time. Engaged in an intermittent dialogue, small-scale adjustments and radical shifts range from planned to unpredictable and institutionalized to insurgent. In a recent essay, Latour and Yaneva (2008) pursue this conceptualization around the movement of space, and condemn conventional architectural representations limited to three-dimensional Euclidean space. They deplore the traditions of picturing buildings as static objects and omitting the complex environment in which physical spaces keep transforming (Latour \& Yaneva, 2008). Architectural drawings fail to address the mutual relationship between space and the relentless flows of change that activate it, alternating between the deterioration of time, users' active appropriations, and renovation projects. Between land and buildings, cities are evolving fabrics. Constructions and 
destructions succeed each other in an imperfect circle, interrupted by gaps and cracks that generate the most striking and permanent urban oddness; they also accommodate the most hidden and ephemeral occurrences. Looking at the recent history of the North Quarter, a neighborhood of Brussels physically enclaved between regional infrastructures, and using Maximilien Park as a spatial anchor in its fabric, this study is an empirical investigation on permanence and ephemerality in the development of urban intersections. The question addressed in this article is: How do different movements of space, time, and people manifest themselves and contribute to the transformation of a central urban tissue and its public spaces?

Four years of ethnographic fieldwork between 2015 and 2019, as well as urban design projects explored during two postgraduate design studios in the fall semesters of 2017 and 2018, conducted in the MaHS-MaUSP masters programs at the University of Leuven (d'Auria, Daher, \& Van Daele, 2019), constitute the background knowledge to address this question. Like an illustrated and contextualized reinterpretation of Lefebvre's spatial triad, the project assembles and confronts everyday spatial practices, as well as conventional representations of space and its multiple symbolic values (Lefebvre, 2014).

Quantitative and qualitative data are assembled and edited in an experimental triptych articulating three panels, picturing the interplay between the apparent stability of an urban environment and the less tangible occurrence of social practices rhythmed by their tireless repetition. The first panel, "Traces," overlaps layers of urban systems that have partially been replaced or have completely disappeared, like the stratification of an excavation site. The second panel, "Cycles," traces back a century of urban regeneration in the North Quarter, unfolding cyclical changes that alternate between components of decay and reclaim, further generating residues open to resignification. The third and last panel, "Resignifications," represents the everyday reappropriation of one of these residues. Across the entire triptych, Maximilien Park stands out, selected as an illustrative example of the North Quarter's recent history: It is a local public space situated along global migration trajectories since 2015, and in which an emergency refugee camp was set up; it is about to be renewed soon and is thus positioned at a moment of transformation. Exploring the methodological question of how to record the temporal conditions of permanence and ephemerality in space, the drawings interrogate and reverse the strict dichotomy that opposes them. Through a casebased process of mapping that is subjective and interpretative, this article aims to present an alternative and differentiated reading of neighborhoods under transformation, showing how perpetual everyday rhythms play an important role in the iterative cycle of urban construction, and how in turn, the spatial layout of a place determines the conditions in which everyday life unfolds.

\section{An Urban Trilogy: Space, Time, and People}

\subsection{Planning Space in Time: The North Quarter}

Like a territory on top of converging tectonic plates, the North Quarter has been continuously re-shaped by external forces of remarkable intensity. In the last decade, large-scale projects flourished all around the area, not only springing up on vacant land, but also demolishing and replacing older structures. This is exemplified today by large-scale real estate development projects, such as "Möbius" (ongoing construction by Assar Architects for Immobel) and "Quatuor" (ongoing construction by Jaspers-Eyers Architects for Befimmo), that replaced the Modernist TBR tower (1976-2017) and the Flemish government's office building Baudouin (1989-2018), respectively. Similarly, temporary occupations preparing the ground for private redevelopment have also been institutionalized in iconic buildings, like the World Trade Center and the Centre de Communication Nord in Brussels in 2018 and 2019, respectively. This activity of demolition and replacement has been initiated and mediated by the application of planning visions and instruments put forth by overlapping governmental institutions in the area. The North Quarter falls within three municipalities, Schaerbeek, Saint-Josse-ten-Noode, and the City of Brussels, all three of which additionally fall under the Brussels-Capital Region (BCR), resulting in a mille-feuilles of superposing urban visions for the area.

These urban planning visions and instruments produced several well-known urban projects, most notably the Manhattan Plan by Groupe Structures (1967-1972) a joint project of the three aforementioned municipalities. Because of the notoriety of the Manhattan Plan, the neighborhood witnessed a pause in urban development for more than two decades. However, since the late 1990s, a renewed interest in the area instigated an appetite for new urban projects. Neighborhood Contracts "Quartier Nord" (1999-2003) and "Masui" (2010-2014) are two such projects initiated by the City of Brussels together with the BCR. Additionally, Urban Renewal Contract "Citroën-Vergote" (2017) by CityTools and Studio Viganò, the "Maximilien-Vergote" Masterplan (ongoing till 2020) by 1010au and Grue, and the upcoming "Vision Territoire Nord" are some notable projects launched by the BCR.

Last year, the BCR in coordination with the public housing company Le Foyer Laekenois launched "Héliport: vers un socle plus ouvert," a call to re-imagine the demolition or renovation of a controversial Modernist plinth built in 1974 by Manhattan Plan author Groupe Structures, in between six high-rise social housing buildings: Héliport (designed by architects Pepermans, Brunfaut, and Lacroix, 1970-1974). Even more recently, in an effort to redefine its public spaces, the BCR announced an open call to redevelop Maximilien Park in November 2019. The call's title, "Max sur Senne," refers not only to the park, but also to the Senne River, which 
was deviated and canalized in the 19th century, then further buried and forgotten since the 1930s, yet continues to flow almost invisibly under the evolving urban fabric. This association of past and present figures to address future changes in space is inherent to the exercise of mapping.

\subsection{Mapping Time in Space: The Palimpsest}

The necessity to explore new formats to visualize interwoven time and space processes, as well as volatile fragments of uncertainty, has been raised at multiple occasions (Corner, 1999; Latour \& Yaneva, 2008). Theoretical approaches have celebrated the map to bear this potential. Mapping, as opposed to tracing, is a creative and qualitative method to analyze and project the local complexity of urban environments. First, it is an iterative process that seeks to understand the formation and composition of a place. Second, it is a filtering exercise, the performance of a subjective and critical layering: maps are abstract objects, purposely showing and hiding elements (Corboz, 1983; Corner, 1999).

Iteration and filter are components that Corboz (1983, p. 24) found in the evolving format of a palimpsest. By overlapping imprints of different eras, a palimpsest records time and tracks changes on the fixed format of a manuscript. The analogy between territory and palimpsest brings in the physical aspect of time. This approach is very inspiring for spatial designers like architects and urbanists, whose main graphic tools include plans and perspectives with the tendency to fix space in a static aesthetic.

Mapping space as a palimpsest could say a lot about previous changes induced by the identification of traces, partly erased layers, and holes, strong erasures, left on its fabric (Corboz, 1983). In these forgotten spaces, the memory of the past seems to prevail on the present (de Solà-Morales, 1995). Paradoxically, such exclusions also contain seeds of future transformations. 'Reality is itself pregnant with fictions that architectures, alternating between the roles of analyst and midwife, can bring into the world,' wrote Marot about Koolhaas' design fascination with the Berlin Wall (Marot, 2013, p. 33). In that context, the word "fictions" evokes the multiplicity of potential futures projected by a multitude of actors on a site. In this research, these latent projects are explored through the active performance of resignifications. Identifying these traces (and holes), resignifications and their contribution to the production of urban space lies at the core of this research, which takes the North Quarter of Brussels and Maximilien Park as test sites.

Additionally, it is important to note that this study takes on a spatial approach to set a methodological framework with which to explore the overlay of spatial conditions with ethnography, and to understand the socio-spatial reproductions that shaped and continue to shape the North Quarter. The site is perceived as a mobile ground, a site that is elastic and provisional, open to continuous change and transformation, where 'diverse realities tip over, into, and out of each other' (Kahn, 2005, p. 290). This concept sets the groundwork for the way in which each piece of the triptych, elaborated on below, is thought about. The illustrations take on a dynamic process that attempts to understand the relations and forces at play, not to 'stabilize meaning, but rather to challenge the very idea of a stable site' (Kahn, 2005, p. 290).

\section{3. (Un)Making Space: Time and People}

Traces and holes materialize as physical mismatches in the urban fabric, as leftovers of uncoordinated additions deconstructing the North Quarter. Assimilated to terrain(s) vague(s), a term first coined by de Solà-Morales in 1995 to describe residual spaces fertile with possibilities, they combine movement and fluctuation, emptiness and availability, imprecision, and uncertainty (de Solà-Morales, 1995). Becoming a canvas open to appropriations, they invite a multitude of resignifications, implicit urban projects performed by everyday users.

Spontaneous and moving urban makers, however, remain largely absent from conventional architectural drawings, like other less tangible but crucial aspects such as economy, logistics and regulations, among others. Progressively, architectural ethnography is emerging as a practice, forcing different perspectives into the urban project. Graphic experimentations have multiplied, enriching the vocabulary and toolbox of spatial designers with more formats and less rules (Daher \& Bosmans, 2019; Kaijima, Stalder, \& Iseki, 2018). Hybrid experiments have brought spatial drawings closer to other disciplines: analogies between art and urbanism (Ungers, 1982), ethnographic fieldwork notebooks (Atelier Bow-Wow, 2010; Trottin, Masson, \& Tallon, 2017), and biological metaphors in architecture (Picon \& Ponte, 2003), to name a few.

This research, conducted at the convergence of social and spatial mapping by three architects and urbanists engaged in ethnographic work, embraces that experimental context. To address urban regeneration in the North Quarter through the interplay of moving space, time, and people, the authors developed a triptych (Figure 1), an illustration composed of three vertical panels side-byside, corresponding to the article's three sections focusing on traces, cycles, and resignifications, respectively. Each panel is designed to illustrate a different view on the same story.

\section{An Urban Triptych: Traces, Cycles and Resignifications}

\subsection{Space and Traces}

Located at the intersection of the three (even four, before the City of Brussels integrated a part of Molenbeek called Faubourg de Laeken in 1921 as part of its maritime extension) municipalities mentioned above, the 


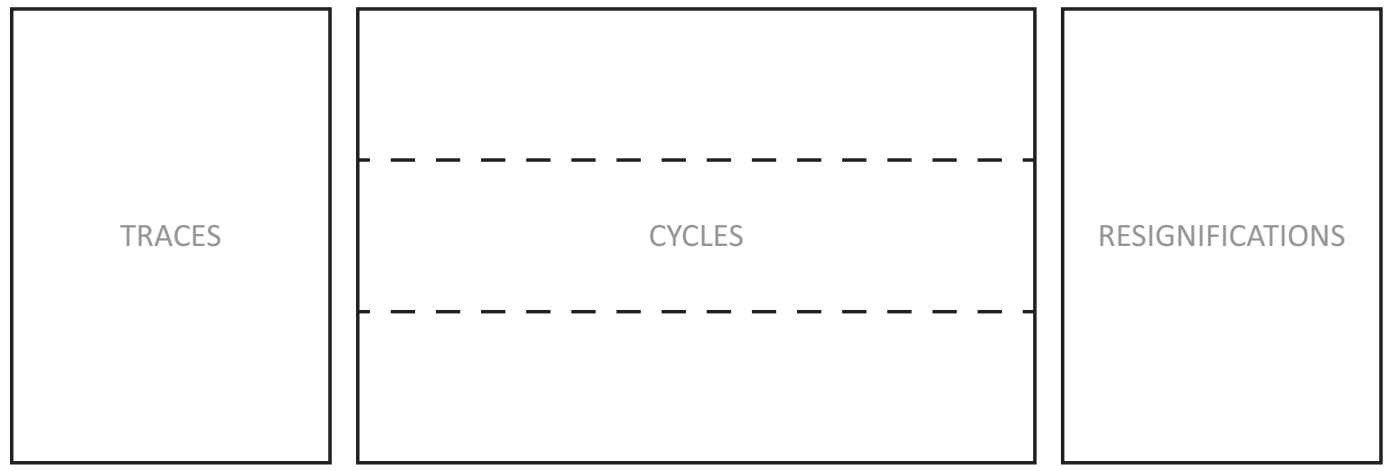

Figure 1. Schematic presentation of the North Quarter's triptych as interpreted by the authors.

North Quarter is an accumulation of socio-spatial diversities: It mixes industrial, artisanal, and office uses, it hosts the city's red-light district, and it has a history of acting as an "arrival city" for migrants hosting thriving multi-ethnic residential neighborhoods (Daher \& Bosmans, 2019; Saunders, 2012). This assemblage of differences physically materializes into three distinct districts. To the north, the old and dense urban block fabric of Masui is composed of small popular houses, ateliers, and warehouses. To the south, Harmonie-former Faubourg de Laeken-displays a 1990s eclectic urban tissue, mixing low, medium, and a few high-rise collective housing buildings. In between those two, Manhattannamed after the business district model that inspired its development-includes a concentration of office towers and a few high-rise social housing blocks. It is this inbetween district that this article focuses on.

The North Quarter's location is squeezed between and isolated by regional infrastructures and mobility routes, as well as at the center of Brussels-a capital continuously reshaped by (inter)national politics-and has generated a chain of uncoordinated cycles of investment and abandonment. Construction and destruction are largely ruled by an accumulation of larger-scale visions and unfinished projects, alternating between permanence and ephemerality. This includes the infamous Manhattan Plan, designed to breathe new life into what was then considered a neglected area, with a vision to turn it into an attractive office district with international allure. This Modernist masterplan to regenerate the area projected the demolition of 53 hectares of traditional urban blocks and the reconstruction of 80 office towers on plinths, but it was canceled a few years after the site's razing, and left a stretch of vacant land for several decades in the middle of Brussels. The area became a "terrain vague," an 'unincorporated margin, an interior island void of activity, oversight,' 'internal to the city, yet external to its everyday use,' a forgotten space 'where the city is no longer' (de Solà-Morales, 1995, p. 120). This traumatic episode, even though it was planned to extend, upgrade, and modernize the region, is part of a longer history of massive destructions dictated by decontextualized interventions. Since the 16th century, largerscale systems colonized, mutilated, and left traces on the original landscape of the Senne River valley: the intricacy of medieval roads linking Brussels to its hinterland, the 1840s building block grid, the 19th century railway and tramway network and corresponding stations, the canals and harbor network, the Senne deviation and coverage between 1931 and 1955, and the 20th century urban highways, viaduct, and metro lines. The area witnessed regional logics overlap, bypass, interrupt, replace, and erase one another with little regard to local realities. Along with time-deterioration, this imperfect assemblage has severely carved the neighborhood's contours and locally produced a constellation of incoherent urban figures, physically inscribed in the fabric but disconnected from its inner logic (de Solà-Morales, 1995).

The left panel of the North Quarter's triptych illustrates the neighborhood's deconstruction through the perspective of space. Figure 2 represents the accumulation of the systems mentioned above. First, in shades of blue, the reader perceives layers of erased urban systems that once composed the urban environment. Second, in red, stand visible traces - the uncertain heritage of the addition and replacement of systems. The following paragraph elaborates on a selection of these lost urban logics and their residues.

In the northern part of the quarter, Rue Masui is a former railway line that connected the industrial harbor of the early 19th century. Rapidly bypassed after the introduction of the Allée Verte station (1835), it evolved into an industrial road which today has an increasing commercial character. Chaussée d'Anvers was first a medieval road (chemin), then called Route d'Anvers, that connected Brussels to Antwerp, but it lost its linking function, and hence its influence, when its role was replaced by new infrastructures, resulting in its downscaling to a local street for popular entertainment studded with small bars and eateries. Avenue de l'Héliport (1958) lies in place of the former Allée Verte railway line-the first built in Belgium - which was demolished in 1954 following the opening of the North-South Junction; the latter's long and intermittent construction (1935-1952) further erased yet another set of urban layers in the eastern part of the district. Part of the obsolete Allée Verte tracks were then converted into a wide street, keeping its remarkable original curvature and width, punctu- 


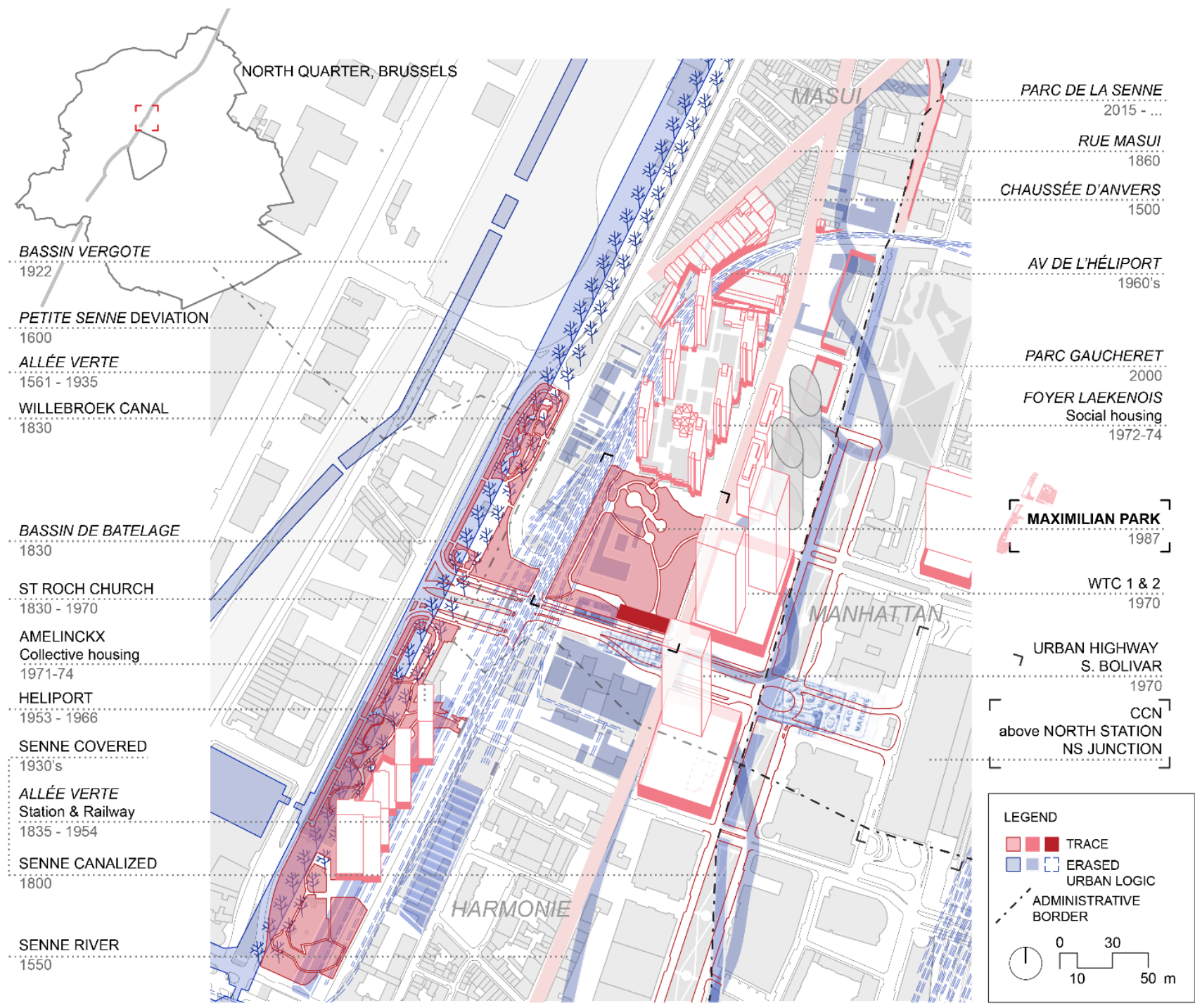

Figure 2. Meshwork of traces and erased urban systems in the North Quarter, Brussels. Credits due to the authors based on a drawing produced by C. Bosmans for the Venice Biennale 2020.

ated by a few industrial backsides and relatively loose alignment. Additionally, Simon Bolivar and Roi Albert II boulevards (1980), neither completed to their planned visions, are testaments to a passed Modernist ambition to turn the North Quarter into a national intersection of highways, crossing in front of a newly inaugurated North Station, rebuilt in 1952 just a few hundred meters away from the original one to serve the North-South Junction. These double, dead-ended, urban highways maintain the oversized width of their unrealized program. Further up north, Parc de la Senne (2015ongoing) is a linear public space being developed inbetween backsides, on the trace of the canalized river. Similarly, Gaucheret Park was implemented in 2000 on land that had remained vacant for three decades, a hole left behind the Manhattan Plan's demolitions and abandonments. Finally, a series of Modernist plinths belonging to the World Trade Center office towers, the Foyer Laekenois social housing complex, and the Amelinckx collective housing buildings pierce the built fabric. These architectural elements, once imagined as part of a network of elevated pedestrian platforms connected with footbridges hovering above urban highways, become "traces" of a vision which never came to life but enriches the area's palimpsest.

Additionally, a significant trace of a lost and unrealized project is Maximilien Park. This seamed patchwork is the result of large pieces torn down from the original fabric as part of the Manhattan Plan, but that also never saw the light of day, leaving large empty holes in the palimpsest, further becoming abandoned and forgotten sites. This undefined series of patches, loosely aligned and fronted by blind plinths and backside walls, were all given the name Maximilien Park in 1987 (Daher \& d'Auria, 2018), as compensation for the troubled implementation of the plan. The longitudinal western part of the park covers centuries (16th-20th) of canal and industrial basin modifications. Moreover, the 18th century bourgeois promenade, Allée Verte, initially the result of digging Willebroek Canal as a towpath (1550), was later 
widened and lined with trees connecting posh leisure activities. The railway line and station's construction shifted attraction away from the promenade and downgraded its reputation. Later, a heliport (1953-1966) was built on a buried basin (bassin de batelage) on the site to serve the World Exposition of 1958, eventually giving its name to the parallel Avenue de l'Héliport. The popular squared part of the park near the World Trade Center towers was developed as a temporary park while waiting for the ever-postponed, and eventually cancelled, construction of towers. On the southern portion of this site also sits the imprint of the old parvis of the Saint-Roch church (demolished in 1971), as an asphalted surface-a mise en abyme of a trace.

\subsection{Time and Cycles}

The central panel of the North Quarter's triptych illustrates the neighborhood's transformation through the perspective of time. Figure 3 pictures the cyclical interaction of traces and resignifications that have shaped the area. To comprehend the complexity of the entanglement, the drawing is elaborated as an iterative timeline on the scientific template of a graph.

The interpretative map reconstructs the urban regeneration processes that stratified the territory over the last century. This technique of highlighting "cycles" of investments, decay, and reclaim was first elaborated in São Paulo, as the legend of a map that explains the production of the city center by social movements and the performance of occupation in an abstract way
(Bosmans, De Beukelaer, Monteiro, \& Van Den Eynde, 2016). Derived from that experience and explored in the design studio with master's students, the North Quarter's production upscales the generic legend to a specific map. In the map shown below, a selective extraction of urban fragments from the fabric allows a detailed investigation of their contribution in the production of the city.

Illustrated in shades of purple, grey, and orange, Figure 3 distinguishes cyclical process of decay and reclaim that predates the appearance of a trace, from top to base as institutional investments, vacancy, and insurgent forces. The upper part of the diagram stages a selection of strategic projects, plans, buildings, and infrastructures extracted out of the enumeration listed in the previous section. The lower part contains swarms of people to represent the occupation of residual spaces, the myriad of resignifications that the neighborhood implicitly contains, which are entangled in migration discourse as will be illustrated later. Displaying cycles of construction, destruction, and reconstruction, the scheme questions the so-called permanence-or stillness-of physical spaces. Getting naturally deteriorated or artificially replaced, urban figures lose their coherence. Finally, illustrated in red on the drawing, stand the traces left by this erosion.

Due to the importance of Maximilien Park in the context of current realities taking place in the North Quarter in recent years, as well as its position as a case study in the doctoral trajectories of both authors, its reproduction is selectively highlighted in the illustration, underlined with a red string (Figure 3). The drawing fol-

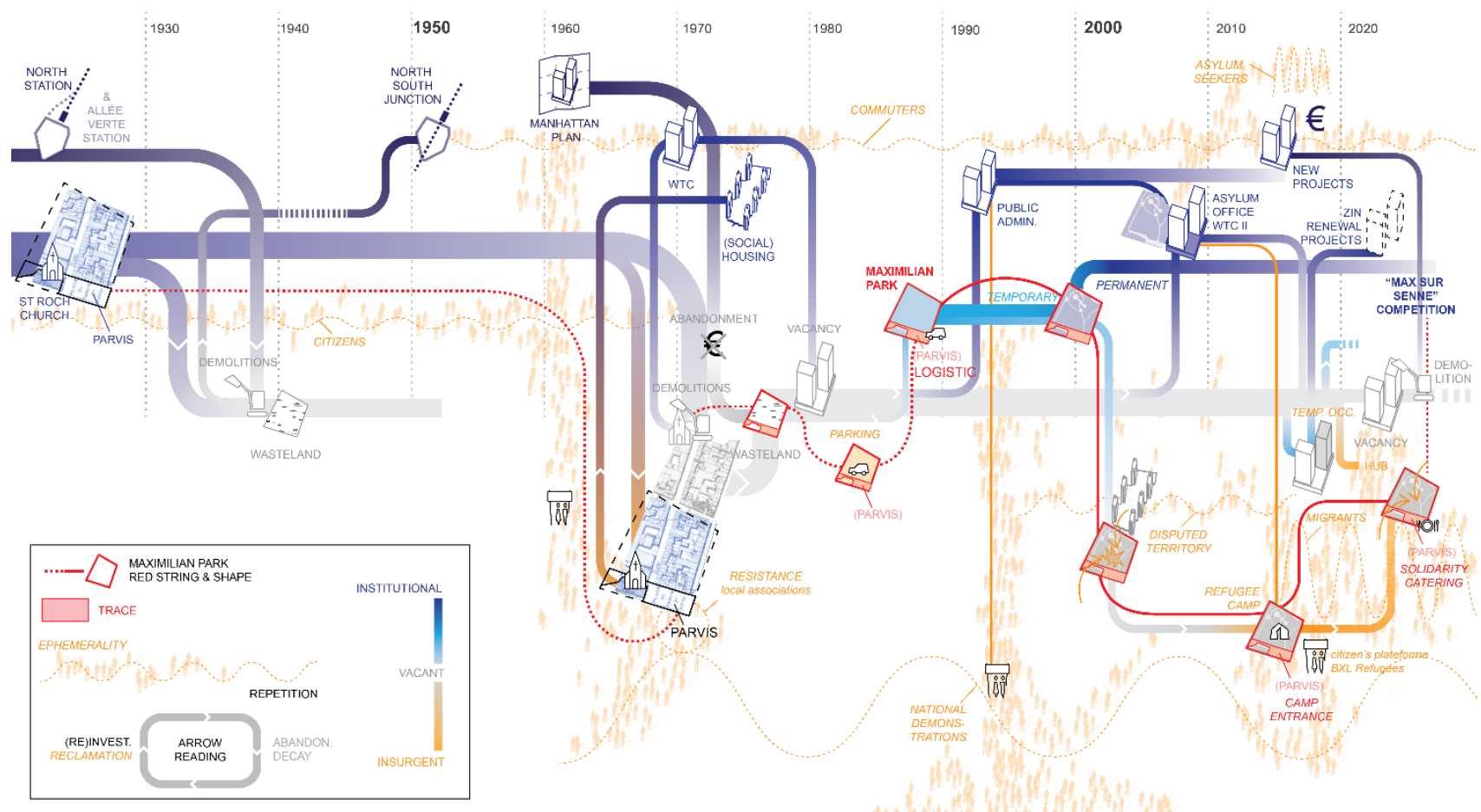

Figure 3. Cycles of decay and reclaim in the North Quarter of Brussels, highlighting Maximilien Park as a trace. Credits due to the authors based on d'Auria et al. (2019) and the Bruxelles Institut Cartographique Militaire (1894). 
lows the evolution of the old parvis of the Saint-Roch church. As a central public space of 19th century fabric and everyday life, it was at the core of local resistance against the Manhattan Plan. The Saint-Roch parish and its social housing service played an active role during the first years of the masterplan's implementation, collecting keys of vacated houses before their imminent demolition and opening them up temporarily to evicted residents and newcomers (mostly immigrant workers) attracted to the area by the growing emptiness and affordability. Close to that square, several local associations and resistance groups were constituted, in response to the demolition (Martens, 2009). After the destruction of the church and the two urban blocks framing the northern part of the parvis in 1971, and following the bankruptcy of the project that delayed reconstruction, spreading its implementation out to forty years, the vacated space turned into a two-decade-long, under-utilized wasteland, used occasionally as parking. In 1987, with the slow reprise of the construction sector in the neighborhood, the City of Brussels set up a temporary park on the vacant building site (Iris Consulting, 1999, p. 11). Today, the southern corner, an asphalted piece inherited from the imperfect demolition of the church site contains the park's maintenance facility, which includes storage of gardening material; it also functions as a parking lot for logistic vehicles. In August 2015, with the increasing influx of refugees fleeing war in their home countries and the so-called "refugee crisis," the park situated across the street from the World Trade Center II Belgian Immigration Office received international attention. The park became an emergency campsite, accommodating up to 1000 migrants and supported by a myriad of volunteers, religious and non-profit organizations. The camp's main entrance was installed on the asphalted surface aforementioned, becoming a strategic meeting point for donation (Depraetere \& Oosterlynck, 2017). Since the dismantlement of the camp about one month after its installation, the southern corner continued to serve both park and migrant logistic needs, including daily coordinated citizen-hosting-action between 2015 and 2019. Additionally, it continued to act as a site for food distribution until the park's closure in April 2020, as a measure to prevent gathering during the Covid-19 pandemic.

As the case of Maximilien park exemplifies, cycles of investments and abandonments are rhythmed by the permanence of traces and ephemerality of spatial appropriations. However, long-term projects typically driven by market speculation and public authorities, and prolonged silences that follow the abandonment and decay of large systems alternate, or rather overlap, with more volatile occurrences performed by users. In parallel to strategies set up by institutions, or according to market interests, de Certeau (2004) highlights the tactics of citizens' appropriations. Identifying a constructive tension that relates tactics to strategies, he claims a comparable evaluation of their impact in the production of space. These tactical uses-both conditioner of and con- ditioned by space-remain largely unrecorded by spatial representations. Nevertheless, some of these practices happen on a recurrent basis, as part of a daily routine like commuting, or an extraordinary yet repetitive event like a public demonstration, to cite a few. This chronic repetition highlights another paradox, inducing the permanent character of ephemeral practices.

On public spaces of the North Quarter, ephemeral uses succeed one another: every day or occasionally, ranging in scale and length, from insurgent to institutionalized, performed out of necessity or to serve profitable interests. On regular occasions, national demonstrations transform its urban highways into claiming stages, stretching out before the ground floors of office towers accommodating public government and large company headquarters. Meeting on the public square in front of the North Station, these massive gatherings pass by Boulevard Roi Albert II, flowing away through urban highways in the direction of the city center and European Quarter. In the built tissue, the World Trade Center I and II towers, emblematic figures of the Manhattan Plan, are now undergoing massive renovations (the "ZIN" project by $51 \mathrm{n} 4 \mathrm{e}$ for Befimmo). Between September 2017 and December 2018, before current renovations began, some portions of their interior spaces were converted for temporary usage, coordinated by the real estate consortium Up4North (AG Real Estate, Allianz, AXA, Banimmo, Befimmo, Belfius Insurance, Immobel and Triuva) in partnership with several design offices (51n4e, Architecture Workroom and Vraiment Vraiment), under the label LabNorth. These temporary uses included renting out office spaces to creative profiles, university-led educational design studios which the authors were part of, and the Rotterdam Architecture Biennale 2018 exhibition "The Future Is Here."

In the shadow of these larger-scale extraordinary events, everyday flows at street-level manipulate the urban space. Masui, a local market selling everything from food to clothes and household devices, opens every Wednesday on the northern section of Chaussée d'Anvers, blocking off vehicular traffic for several hours. Five days a week, commuter flows cross and fill the urban highways that divide the neighborhood into three districts: Harmonie, Masui, and Manhattan (locally called "les Blocs"). Walking through the physical and psychological borders created by Simon Bolivar and Roi Albert II boulevards, the masses move along the edges of inhabited territories, carving the separating lines as they open and close shop frontages and terraces serving business lunches.

\subsection{People and Resignifications}

The right panel of the North Quarter's triptych, Figure 4, illustrates the neighborhood's through the perspective of individuals occupying Maximilien Park and utilizing its infrastructure. It pictures the everyday life that unfolds, recording fluctuations and patterns of local uses 
by documenting the behaviors of its current usersundocumented migrants, volunteers, and inhabitants, among others. The focus shifts from the spatial arrangement of traces and the transformation of the city through cycles in time, to tactical resignifications that react to and adjust its loose physical reality. The drawing illustrates the re-appropriation and use of spatial features in the park, materializing conflicts and negotiated meanings. By this re-appropriation, the park is constantly in motion, transforming with and by its users manifesting their struggles in urban public space.

Spending extended periods of time in Maximilien Park on many occasions, throughout different times of day and weather conditions, allowed the collection of

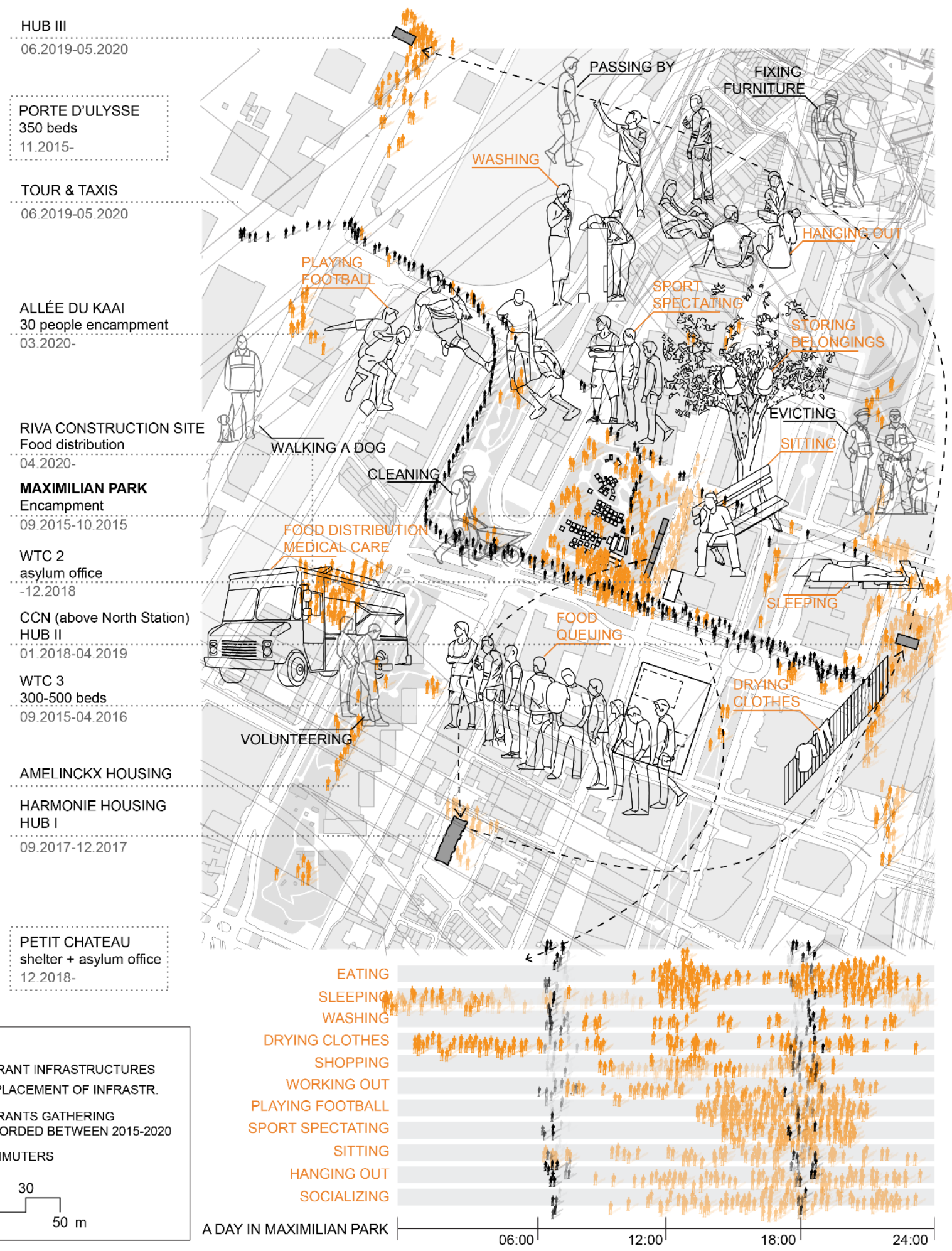

Figure 4. Maximilien Park: Occupation and resignifications. Credits due to the authors based on Daher \& Bosmans (2019). 
data through observation, writing, sketching, drawing, and interacting with users through formal and informal conversations. Their embodied presence is synthesized in Figure 4, overlaid onto a plan of the park within its urban context.

The illustration first shows how the park's public space and its infrastructure are re-signified for the uses of undocumented migrants currently inhabiting it. For example, a water fountain serves as shower and laundry service for washing, and a fence is used as a drying rack for clothes; vast grassy spaces under trees become open-to-sky bedrooms, with flattened cardboard boxes serving as mattresses to sleep on. Some days, tree branches are curiously charged with backpacks, used as storage for personal belongings. Other more common park activities such as sitting on benches, playing sports, and group-socializing occur in the park too. However, the presence of undocumented migrants for entire days converts its use from a place of recreation to one of collective domesticity (Daher, 2019), and not without conflict. From the many conversations had during ethnographic work, neighbors recurrently expressed empathy about undocumented migrants being forced to use the park for their most basic needs, as well as feeling unsafe by their presence. In contrast, the migrants expressed that their collective presence offers a sense of safety, despite frequent police-raids occurring unexpectedly or according to a locally well-known weekly schedule: every Wednesday morning before seven-thirty.

In addition to the re-appropriations by undocumented migrants, other users' activities are also illustrated, including facility workers cleaning the park or fixing an object, inhabitants passing by or walking their dogs, as well as citizen-volunteering efforts, contrasted by police evictions. The bottom of the figure displays a time-sharing interpretation of uses that seemingly dominate Maximilien Park's daily rhythm, composed mainly of the mundane activities of domestic life: eating, sleeping, shopping, and group-socializing activities that make life in the park livable (Daher \& Bosmans, 2019). More about the park and activity of undocumented migrants have been described in previous writings (ARCH, 2019; Daher, 2019; Daher \& Bosmans, 2019; Daher \& d'Auria, 2018).

A second layer of information is revealed in Figure 4: the changing locations where clusters of undocumented migrants congregate (represented as orange silhouetted human figures). The illustration shows masses that once existed (faded orange silhouettes) at important moments in time, since 2015. Similarly, commuter pathways through public spaces of the North Quarter are represented as black silhouetted figures. This group turns the park into passage-a shortcut on their way from home to work across the canal. In parallel, undocumented migrants on their long journey towards asylum occupy the park; for them, the park is also a place of passagea pit-stop in their larger journey toward the UK. Their numbers, changing demographics, and activities have reshaped the park since 2015, fluctuating with different political events related to asylum in the past few years, marked by that moment when the emergency camp turned the park into a contested space for the playing out of citizenship and acts of citizenship (Depraetere \& Oosterlynck, 2017).

Along with moving masses, Figure 4 further shows the three relocations of the Humanitarian Hub (operated by the Citizen's Platform for Refugee Support) which provides access to professional and domestic services to undocumented migrants. Its displacement had an effect on their movements, changing their spatial pattern in the area, while maintaining the Hub's state of precarity in its temporary occupations. In September 2017, it first opened in the Harmonie district near Amelinckx collective housing complex; it then relocated to an empty space on the first floor of the Centre de Communication Nord building in the North Station, from January 2018 to May 2019, before finally moving to another empty office building near the Tour et Taxis site, where it currently operates from. Similarly, night shelters opened and closed in empty local spaces: the World Trade Center III between 2015 and 2016, and the underground entry level of the North Station's bus platforms, between February and May 2019 (Daher, 2019). In 2018, the Immigration Office was relocated to "Le Petit Chateau," a nearby shelter for asylum seekers. Even though the queue in front of the former location which once filled up the sidewalk at World Trade Center II on Chaussée d'Anvers disappeared, Maximilien Park remains a strategic meeting place for the gathering of undocumented migrants. Ultimately, the park behaves as pars pro toto of the North Quarter, inseparable from its palimpsest. It has become an intersection of crossing agendas, inhabited districts, infrastructures, and public spaces, as well as multiple scales-global, national, and local-and is continuously reshaped by them.

Like the cycles of physical transformation illustrated on the central panel, periodic manifestations recorded in the park also leave other traces on the neighborhood. From waste material scattered across public space, to deteriorated vegetation after a large gathering, to the personal belongings left behind, these "traces" betray their users' absence when they are not in the park. Such manifestations sometimes cause volatile situations with building residents nearby. Spatial practices leave marks and continuously participate in the production of the urban environment. The collective presence of users and materialization of their activities imprints an image of misappropriation in the memory of local inhabitants, transforming the meaning of a place, as has been experienced in the North Quarter. As such, they further create conditions for contestation and conflict. As a counter-reaction, fences and control devices, as well as the suppression of benches, have occurred to alter the lived experience (Dresler, 2019).

The illustration of users and their repetitive daily activities in the park, the relocation of services addressed to undocumented migrants, and the movement 
of masses are all attempts to expand on architectural ethnography in urban representations, providing insight on the social production of space in the city. It is also a proposition to illustrate the non-fixity of public spaces' meanings and their transformative and changing nature. Additionally, humanizing the architectural and urban drawing with its user-groups and appropriated spaces describes spatial settings as provisional and constantly negotiated. However, both architectural ethnography and sensitivity towards undocumented migrants' political status highlight the ethical question of their representation. By portraying their embodied presence, the drawings expose only what can already be seen, but is usually ignored by urban projects. As users involved in the space of city, this group has as much right as any other to be represented by and of the city.

Importantly, this type of mapping goes beyond the dominant conception of public spaces, alluding to the notion of 'right to the city' as the right to an urban lifea value system that consists of the interests of the entire society and those who inhabit the city without distinction (Lefebvre, 1968, p. 35). As such, solidarity movements like the Citizen's Platform for Refugee Support are important to include in urban discourse, because they operate out of moral and humanist values that may conflict with legal structures in place. They highlight activist and citizen positions about the kind of city they want to live in, manifesting the right to the city as Harvey (2003, p. 939) described it: the right to 'change ourselves by changing the city...a collective right rather than an individual right.... The freedom to make and remake ourselves' by remaking the city. Celebrating this right through mapping, this work is also an attempt to bring and force this claim up to planning levels.

Insurgent appropriations find fertile terrain in residual spaces; gaps and cracks in the urban fabric open up opportunities to creatively inhabit the city in alternative ways, reacting to or taking advantage of looseness and disorder. De Solà-Morales (1995, pp. 119-120) describes these gaps as places of possibility and freedom, liberated from constraint, places of 'movement, oscillation, instability, and fluctuation' and places of contrast between 'void and promise.' Like a void, a "hole" in the fabric, the trace of destruction and aborted vision, Maximilien Park as represented in Figure 4 is exemplary of that claim. Public and green by default, this space lying in-between urban highways and blind walls was not framed by any residential façade until recently. Its situation on the edge of the residential neighborhoods Harmonie, "les Blocs," and Masui, amplifies its bordering and interstitial character. On that unbuilt terrain, successive additions, transformations, and demolitions, as well as abandonments, temporariness, and over-design, accumulate to co-produce a space that challenges the conventional park. For undocumented migrants, the park has become a place of promise of a future only possible through migration (Meeus, van Heur, \& Arnaut, 2019). Their embodied presence in this urban site makes them 'social ac- tors who are integral to city-making as they engage in the daily life' of the city (Çağlar \& Glick Schiller, 2018, p. 5). Using the framework of the triptych, we perform a 'multiscalar analysis' in which we include migrants and their everyday, city-making processes within the 'historic conjuncture' (Çağlar \& Glick Schiller, 2018, pp. 13, 16) of the multiple actors, users, and forms of power that have affected the North Quarter over time, composing its palimpsest.

From a spatial perspective, conflicting and negotiated practices have produced, adjusted, and maintained the interstitial condition of the space for a few decades. Yet, the lack of power over the activity in the park instigates a sense of anxiety, among politicians and residents, of the area becoming a physical expression of 'fear and insecurity' (de Solà-Morales, 1995, p. 121). However, even before being appropriated by undocumented migrants, the park was already identified as disputed territory between different youth groups in the first Neighborhood Contract “Quartier Nord” (Iris Consulting, 1999, p. 16).

\section{Conclusion}

This article elaborates on interpretative and subjective forms of mapping and takes the North Quarter, a central and highly diverse area under regeneration, and Maximilien Park as pars pro toto, as a case-study to theoretically contribute to the notion of the "palimpsest" in urban design. The empirical exercise mobilizes drawing as a critical and analytical, as well as an illustrative and projective, tool. The palimpsest in this article is built up as a triptych, conceptually divided into three panels picturing three perspectives: space as traces, time in cycles, and people in resignifications.

In "Traces," the panel identifies a constellation of spatial mismatches and terrains vagues in the area that articulate the imperfect urban collage through an apparent emptiness. Their presence simultaneously informs the existence of lost meanings that once activated the place in previous times, and recall the diversity the place has been constructed on and accumulated.

In "Cycles," the panel traces back the formation of traces to unravel and understand the different logics that animated and produced the urban fabric. The drawing presents the important tension between institutional and insurgent forces underpinning this construction, rhythmed by half-realized, long-term visions, as well as lifelong projections being performed on a daily basis.

In "Resignifications," traces appear not only to be passive remnants, but also to carry opportunistic potentials. Traces possibly stage and prefigure spatial interventions and practices that are continuously adjusting the urban tissue with their own means and perspectives, and according to their own interests. Traces represent resilience because they transcend the circumstances that created their existence, or rather attempted to eliminate them, as articulations in time. They are the result of fictitious visions, for better or worse. They 

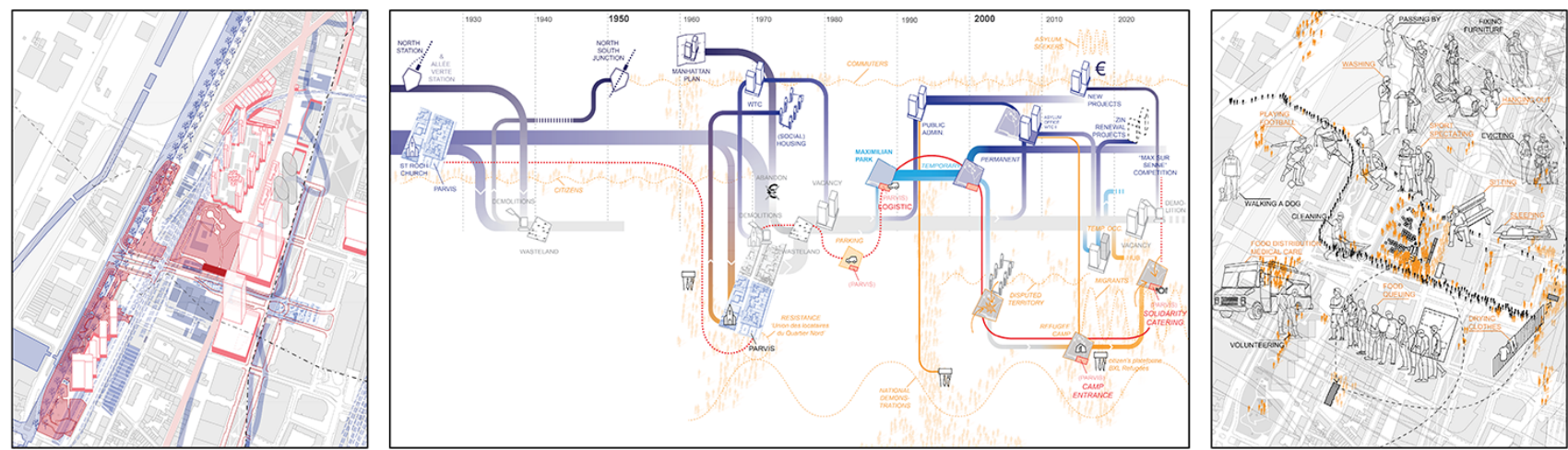

Figure 5. The North Quarter's palimpsest as a multi-scalar triptych.

are spaces where futures are imagined, projected, and tested. These spaces become spatial resignifications being performed and therefore implicitly brought to reality by a long list of local stakeholders and everyday life. Tirelessly reiterated and continuously adjusted, resignifications transform local meanings and lived realities, in turn leaving marks in the local fabric and in local memory. Resignifications of traces can also be collaborative productions between different levels of power, including real estate developers and institutions, as the explosion of temporary occupation attests. However, in the shadow of the radical transformations that architecture and urbanism tend to project on vacant land, traces are implicit and almost self-reproducing. Seemingly, resignifications are not only waiting for architects to realize them. Unravelling the palimpsest is a patient encounter and unravelling of fluctuations, ephemeral forces and rhythms that formulate the continuity on which an urban environment regenerates itself.

As the example of Maximilien Park shows, undocumented migrants found, out of necessity, openness, and flexibility to survive in an interstitial space bordering several neighborhoods in the area. Their collective presence sheds light on forgotten spaces-traces-located in the urban fabric of the North Quarter. By their massive appropriations-which are not without conflictthey have transposed a new set of meanings on the "terrain vague," requalifying its role in the disrupted urban ecosystem. These resignification processes are fluid and mobile, triggering new dynamics that challenge vacancy and looseness, to open up new spaces for upcoming needs. Resignification calls for more resignification: The slow but incremental construction and consolidation of hospitable, yet temporary, infrastructure since 2015 is encouraging. However, as the example of undocumented migrants and the perpetual relocations show, resignifications tend to stay in loose spaces and in precarity. The internal movement and temporariness that characterize their situation is quite explicit, not only in their presence and appropriations in the park, but also in the support structure they receive, such as the Humanitarian Hub which relocated three times in four years. Similarly, "Max sur Senne," the latest public call by the City of
Brussels to renew Maximilien Park, never mentions its current occupants.

Finally, the representation of the North Quarter's palimpsest in the framework of the triptych (Figure 5), allows the creation of a layered, multi-scalar, and analytical reading loaded with meanings. It is also a way to illustrate the non-fixity and fluidity of an area, as a space subject to constant change, further opening up room for future flux. It offers the potential to document the permanence and ephemerality of an area, the multiple forces at play, as well as user appropriations of space.

After having mapped the palimpsest as a mobile ground, a new question emerges: If traces are locally reproduced into resignifications, what is the role of the spatial designer? In an era of rapid changes, intensified flows, and increased speeds, a next challenge would be to integrate these local fluctuations in the urban project: to focus on designing a process that is always negotiated, rather than designing a fixed project. As Latour and Yaneva (2008) call for in their essay, the spatial designer must embrace this moving complexity as a working framework. The palimpsest as a triptych bears that potential.

\section{Acknowledgments}

The authors would like to thank ARCH for providing a platform to deepen ethnographic work, as well as the users of Maximilien Park for exchange that aided the research. They would also like to thank the students of MaHS-MaUSP Urban Design Fall Studios of 2017-2018 and 2018-2019, for putting together critical base drawing work in the analysis phase. Finally, they would like to thank Austin Sakong for very generously accepting to proofread this article. This publication was made possible through funding support of the KU Leuven Fund for Fair Open Access.

\section{Conflict of Interests}

The authors declare no conflict of interests. 


\section{References}

ARCH. (2019). Whose future is here? Searching for hospitality in the North Quarter of Brussels. Brussels: Metrolab Series.

Atelier Bow-Wow. (2010). Behaviorology. New York, NY: Rizzoli International Publications.

Bosmans, C., De Beukelaer, K., Monteiro, R., \& Van Den Eynde, V. (2016). Occupying central São Paulo. The proto-urbanisms of central movements (Unpublished Master's thesis). KU Leuven, Leuven, Belgium.

Bruxelles Institut Cartographique Militaire. (1894). Bruxelles et ses environs [Brussels and its surroundings; Cartographic document]. XXXI Bruxelles (1894ICM-IV 3336). The Royal Library of Belgium, Brussels, Belgium.

Çağlar, A., \& Glick Schiller, N. (2018). Migrants \& citymaking: Dispossession, displacement, and urban regeneration. Durham, NC: Duke University Press.

Corboz, A. (1983). The land as palimpsest. Diogenes, 31(121), 12-34.

Corner, J. (1999). The agency of mapping: Speculation, critique and invention. In D. Cosgrove (Ed.), Mappings (pp. 213-252). London: Reaktion.

d'Auria, V., Daher, R., \& Van Daele, E. (2019). North side stories: Concepts and analysis urban design studio. Leuven: MAHS-MAUSP, KU Leuven.

Daher, R. (2019). (Un)making home: Displacement, domesticity and solidarity in the North Quarter of Brussels. In A. Gola, A. Singh, \& A. Singh (Eds.), Displacement \& domesticity since 1945: Refugees, migrants, and expats making homes. (pp. 343-353). Leuven: KU Leuven.

Daher, R., \& Bosmans, C. (2019). Mapping the undocumented: Recording ephemerality in the Northern Quarter of Brussels. In Whose future is here? Searching for hospitality in Brussels Northern Quarter (pp. 27-39). Brussels: ARCH and Metrolab Series.

Daher, R., \& d'Auria, V. (2018). Enacting citizenship in an urban borderland: The case of the Maximilien Park in Brussels. European Journal of Creative Practices in Cities and Landscapes, 1(1), 53-72.

de Certeau, M. (2004). The practice of everyday life. 'Making do': Uses and tactics. In G. M. Spiegel (Ed.), Practicing history: New directions in historical writing after the linguistic turn (pp. 229-289). London: Routledge.

de Solà-Morales, I. (1995). Terrain vague. In C. C. Davidson (Ed.), Anyplace (pp. 118-123). New York, NY: Anyone Corp.

Depraetere, A., \& Oosterlynck, S. (2017). 'I finally found my place': A political ethnography of the Maximiliaan refugee camp in Brussels. Citizenship Studies, 21(6), 693-709.

Dresler, A. D. (2019). Time-lapses of the Northern Quarter's public space. In Whose future is here? Searching for hospitality in Brussels Northern Quarter (pp. 42-47). Brussels: ARCH and Metrolab Series.

Harvey, D. (2003). The right to the city. International Journal or Urban and Regional Research, 27(4), 939-941.

Iris Consulting. (1999). Contrat de Quartier Nord [Neighborhood Contract "Quartier Nord"]. Brussels: Iris Consulting.

Kahn, A. (2005). Defining urban sites. In C. J. Burns \& A. Kahn (Eds.), Site matters: Design concepts, histories, and strategies (pp. 281-296). New York, NY: Routledge.

Kaijima, M., Stalder, L., \& Iseki, Y. (2018). Architectural ethnography. Tokyo: Toto Publishing.

Latour, B., \& Yaneva, A. (2008). 'Give me a gun and I will make all buildings move': An ANT's view of architecture. In R. Geiser (Ed.), Explorations in architecture: Teaching, design, research (pp. 80-89). Basel: Birkhäuser.

Lefebvre, H. (1968). Le droit à la ville [The right to the city]. L'Homme et la société, 6(1), 29-35.

Lefebvre, H. (2014). The production of space. In J. J. Gieseking \& M. Mangold (Eds.), The people, place, and space reader (pp. 289-293). New-York, NY: Routledge.

Marot, S. (2013). The genesis of a hopeful monster. In F. Hertweck \& S. Marot (Eds.), The city in the city: Berlin: A green archipelago (pp. 25-43). Zurich: Lars Müller Publishers.

Martens, A. (2009). Ten years of expropriations and evictions in the Brussels North Quarter (1965-1975): What are the legacies today? Brussels Studies, 29(29), $1-15$.

Meeus, B., van Heur, B., \& Arnaut, K. (2019). Migration and the infrastructural politics of urban arrival. In $B$. Meeus, K. Arnaut, \& B. van Heur (Eds.), Arrival infrastructures: Migration and urban social mobilities (pp. 1-32). Switzerland: Palgrave Macmillan.

Picon, A., \& Ponte, A. (2003). Architecture and the sciences: Exchanging metaphors (Vol. 4). Princeton, NJ: Princeton Architectural Press.

Saunders, D. (2012). Arrival city: How the largest migration in history is reshaping our world. New York, NY: Vintage Books.

Trottin, D., Masson, J.-C., \& Tallon, F. (2017). Usages: Tokyo. Paris: IN-EX project.

Ungers, O. M. (1982). Morphologie: City metaphors. Köln: König. 


\section{COGITATIO}

\section{About the Authors}

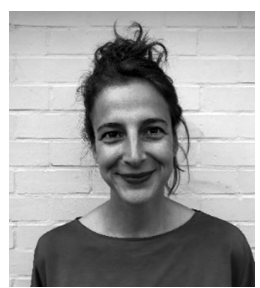

Claire Bosmans is a PhD Candidate at the OSA research group of KU Leuven. She holds a Master's in Architecture from the Brussels based LOCI Faculty of UCLouvain and a post-Master's in Urbanism and Strategic Planning from KU Leuven. Her research focuses on Modernist social housing estates in Brussels and their residents, combining architecture, urbanism and ethnography through drawing and design experiments. She is a member of $\mathrm{ARCH}$ working on urban hospitality in Brussels North Quarter.

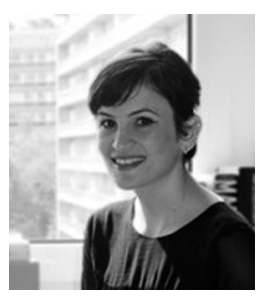

Racha Daher is a PHD Candidate at KU Leuven exploring the question of urban inclusion and urban citizenship in an age of migration. Her research uses the North Quarter of Brussels as a contextual base case to study mobile social and spatial ecologies and their urban manifestations in public space. She is trained as an architect and holds a Master's in Urban Design from Columbia University. She is a member of $\mathrm{ARCH}$ and is co-founder of Hive Public Space.

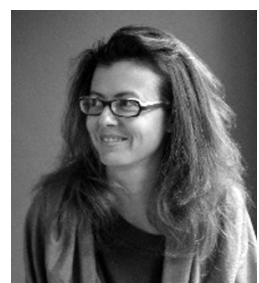

Viviana d'Auria trained as an Architect-Urbanist at Roma Tre University, Italy, and pursued postgraduate studies in Human Settlements at the KU Leuven, where she also completed her doctoral dissertation. Viviana is currently Assistant Professor in International Urbanism at the Department of Architecture, Faculty of Engineering, KU Leuven. Her interest in integrating insights from ethnography and design has led to several collaborations and research projects, within a more general inquiry in the trans-cultural construction of cities and their contested spaces. 